\title{
Characteristics of Nutrition, Growth, Carcass and Meat of Male Goats Fed Babassu Mesocarp Flour
}

\author{
Aylpy R. D. Santos ${ }^{1}$, Jarlyanne N. C. Souza ${ }^{1}$, Henrique N. Parente ${ }^{1}$, Graziele S. Oliveira ${ }^{1}$, \\ Karlyene S. Rocha ${ }^{1}$, Anderson M. Zanine ${ }^{1}{ }^{1}$, Daniele J. Ferreira ${ }^{1}$, Anny G. V. O. Lima ${ }^{1}$, \\ Jocelio S. Araújo ${ }^{1}$ (D) Arnaud A. Alves ${ }^{2}$ (D) and Michelle O. M. Parente ${ }^{1, * D}$ \\ 1 Department of Animal Science, Federal University of Maranhão, Chapadinha, Maranhão 65500-000, Brazil; \\ renanufma@hotmail.com (A.R.D.S.); lyannecsouza46@gmail.com (J.N.C.S.); \\ hnparente@hotmail.com (H.N.P.); grazizootec7@gmail.com (G.S.O.); karlyene_sousa@yahoo.com.br (K.S.R.); \\ anderson.zanine@ibest.com.br (A.M.Z.); dany_dosanjos@yahoo.com.br (D.J.F.); \\ annygraycy@gmail.com (A.G.V.O.L.); jocelios@yahoo.com.br (J.S.A.) \\ 2 Department of Animal Science, Federal University of Piauí, Teresina, Piauí 64049-550, Brazil; \\ arnaud@ufpi.edu.br \\ * Correspondence: michellemrn14@gmail.com
}

Received: 2 June 2020; Accepted: 8 July 2020; Published: 10 July 2020

\begin{abstract}
Twenty-eight Boer $\times$ Saanen castrated male goats $(21.6 \pm 3.0 \mathrm{~kg}$ of initial body weigh) were distributed in a randomized complete block design to evaluate the effects of increasing levels $(0,100$, 200 or $300 \mathrm{~g} / \mathrm{kg}$, in dry matter basis) of dietary babassu mesocarp flour (BMF) on performance, nutrient digestibility, carcass characteristics, and meat physical and chemical composition. When significant treatment effects were found, data were submitted to orthogonal polynomials for treatment responses. BMF did not change the intake and digestibility of dry matter and crude protein. However, it increased linearly the total carbohydrates intake $(p=0.013)$, neutral detergent fiber intake $(p<0.001)$ and digestibility $(p=0.027)$, while it decreased linearly the intake of non-fibrous carbohydrates $(p<0.001)$ and ether extract $(p<0.001)$, without changing their digestibility $(p>0.05)$. The dressing percentage $(p=0.003)$ and rib eye area $(p=0.024)$ had a quadratic effect with increasing levels of BMF. The total gastrointestinal weight (TGI) had an increased linear effect $(p=0.001)$, while the proportion of rumen $(p=0.010)$, omasum $(p<0.001)$ and abomasum $(p=0.001)$ increased linearly with BMF addition. The same effects were presented in leg weight $(p=0.045)$ and muscle weight $(p=0.049)$. Weight and yields of commercial cuts and meat physicochemical composition did not change $(p>0.05)$ with inclusion levels of BMF. The addition of babassu mesocarp flour up to $200 \mathrm{~g} / \mathrm{kg}$ in the diet of male goat can improve the dressing percentage without major changes in meat physical and chemical traits, representing an attractive alternative feed.
\end{abstract}

Keywords: average daily gain; co-product; commercial cuts; fiber digestibility; Longissimus lumborum

\section{Introduction}

The modernization of agribusiness has made Brazil the largest producer of food located in the tropical region. Brazil has been the world's first largest global corn producer [1], however, the use of both corn and soybeans has grown substantially over the last 15 years, supported mostly by feed use, especially in intensive production systems.

The feedlot system is an efficient strategy to reduce the age at slaughter and to increase average daily gain, resulting in an increment of meat production. However, there is a greater demand for grains, which are also used in human nutrition, in formulation of diets. Because of this, studies with co-product addition to replace conventional grains in ruminant diets have increased [2-4]. 
Among many vegetable species in Brazil, babassu (Attalea speciosa) is a palm tree found between the Cerrado and the Amazon Forest, which is native to the northern and northeastern states of Brazil [5]. The babassu coconut comprises the epicarp, mesocarp, endocarp, and kernel, each accounting for $110,230,590$, and $70 \mathrm{~g} / \mathrm{kg}$ of the total mass, respectively [6]. The oil extracted from their kernels is marketed locally and the important co-products are available during the off-season of conventional grains, thus making it an important alternative to regional producers.

The babassu mesocarp flour (BMF), extracted from mesocarp, is offered in the market at low cost. It is considered an energetic ingredient because of the high starch content [7] and has been used to replace ground corn in the diets of lambs [3,4].

Except for a few studies with lambs [3,4] that reported a decrease in dry matter intake, nutrient digestibility, and average daily gain, there is no available information on the efficacy of babassu mesocarp flour (BMF) addition in male goat diets. It is known that goat species are more efficient in fiber digestibility [8], and because of this, we hypothesized that male goats fed diets with BMF addition would have similar growth performance, carcass characteristics, and meat quality as those fed diets with conventional grains in the diet.

Thus, the aim of this study was to determine the effects of increasing levels of BMF in diets of finishing male goats on growth, nutrient digestibility, and carcass characteristics, as well as the physical and chemical composition of the meat.

\section{Materials and Methods}

\subsection{Location, Animals and Experimental Facilities}

The experiment was conducted at the Small Ruminant Sector, Center of Agrarian and Environmental Sciences, Federal University of Maranhão, located in Chapadinha, MA ( $03^{\circ} 44^{\prime} 33^{\prime \prime}$ S, $\left.43^{\circ} 21^{\prime} 21^{\prime \prime} \mathrm{W}\right)$, Brazil. All animal use procedures were according to the guidelines recommended by the Animal Care and Use Committee at the same institution (Process number 23115.010734/2016-81).

A total of 28 Boer-Saanen castrated male goats, with an initial average body weight (BW) of $21.6 \pm 3.0 \mathrm{~kg}$ and average age of 8 months were used in the study. Castrated males were used because in confinement it is the animals that present performance responses close to whole males and these animals have the quality meat most desired by the consumer market, especially considering the organoleptic characteristics. The animals were housed in covered pens (one animal per pen; $0.75 \mathrm{~m} \times 1.50 \mathrm{~m}$ ) with concrete floors for 58 days: 12 days for the adaptation of animals to the diets and management and 46 days for the experimental period. All animals were dewormed with $2.5 \mathrm{~g} / \mathrm{kg}$ monepantel at a dose of $1 \mathrm{~mL} / 10 \mathrm{~kg}$ of body weight before the start of the experiment.

During the experimental period (from September to November, 2017), the mean relative humidity was $65 \%$, while the minimum and maximum temperature registered were $25.4{ }^{\circ} \mathrm{C}$ and $40.1{ }^{\circ} \mathrm{C}$, respectively [9]. The length of light day is about $11 \mathrm{~h}$.

\subsection{Experimental Design, Feeding Management, and Data Collection}

The male goats were distributed in a completely randomized design, with four treatments, and the initial weight of animals was used as covariate.

The experimental diets (Table 1) were defined by the addition of BMF (Florestas Brasileiras S.A., Itapecuru Mirim, MA, Brazil; Table 2) and contained $700 \mathrm{~g} / \mathrm{kg}$ (in dry matter basis, DM) of concentrate and $300 \mathrm{~g} / \mathrm{kg}$ DM of forage (Tifton-85 hay) [10]. The treatments were as follows: (1) control diet without BMF, (2) inclusion of $100 \mathrm{~g} / \mathrm{kg} B M F$, (3) $200 \mathrm{~g} / \mathrm{kg} \mathrm{BMF,} \mathrm{and} \mathrm{(4)} 300 \mathrm{~g} / \mathrm{kg}$ BMF. Experimental diets were fed as total mixed rations every other day at $08.00 \mathrm{~h}$, and animals were allowed ad libitum access to feed and fresh water. 
Table 1. Proportion of ingredients and chemical composition of experimental diets in $\mathrm{g} / \mathrm{kg}$ of dry matter.

\begin{tabular}{|c|c|c|c|c|}
\hline \multirow{2}{*}{ Ingredients } & \multicolumn{4}{|c|}{ Babassu Mesocarp Flour (g/kg DM ${ }^{3}$ ) } \\
\hline & 0 & 100 & 200 & 300 \\
\hline Tifton-85 Hay & 300.0 & 300.0 & 300.0 & 300.0 \\
\hline Ground corn & 480.0 & 370.0 & 260.0 & 150.0 \\
\hline Soybean meal & 110.0 & 120.0 & 130.0 & 140.0 \\
\hline Babassu mesocarp flour & 0.0 & 100.0 & 200.0 & 300.0 \\
\hline Wheat bran & 100.0 & 100.0 & 100.0 & 100.0 \\
\hline Mineral premix 1 & 8.0 & 8.0 & 8.0 & 8.0 \\
\hline Limestone & 2.0 & 2.0 & 2.0 & 2.0 \\
\hline \multicolumn{5}{|c|}{ Chemical composition (g/kg DM) } \\
\hline Dry matter (g/kg FM $\left.{ }^{2}\right)$ & 885.0 & 884.0 & 882.0 & 881.0 \\
\hline Ash & 39.0 & 41.0 & 43.0 & 45.0 \\
\hline Crude protein & 127.0 & 127.0 & 127.0 & 127.0 \\
\hline Ether extract & 42.0 & 39.0 & 35.0 & 32.0 \\
\hline Neutral detergent fiber & 345.0 & 381.0 & 416.0 & 456.0 \\
\hline Acid detergent fiber & 165.0 & 189.0 & 213.0 & 237.0 \\
\hline Non-fiber carbohydrates & 444.0 & 411.0 & 377.0 & 339.0 \\
\hline Total carbohydrates & 790.0 & 792.0 & 794.0 & 795.0 \\
\hline Metabolizable energy, Mcal/kg & 2.8 & 2.9 & 2.9 & 2.8 \\
\hline
\end{tabular}

Table 2. Chemical composition of babassu mesocarp flour $\mathrm{g} / \mathrm{kg}$ of dry matter.

\begin{tabular}{cc}
\hline Chemical Composition & Babassu Mesocarp Flour \\
\hline Dry matter $\left(\mathrm{g} / \mathrm{kg} \mathrm{FM}^{1}\right.$ ) & 875.0 \\
Organic matter & 970.9 \\
Mineral matter & 29.1 \\
Crude protein & 49.4 \\
Ether extract & 17.1 \\
Neutral detergente fiber & 463.9 \\
Acid detergente fiber & 260.1 \\
Non-fiber carbohydrates & 440.5 \\
Total carbohydrates & 904.4 \\
\hline
\end{tabular}

${ }^{1} \mathrm{~g} / \mathrm{kg}$ FM-grams per kilograms of fresh matter.

Corn was coarsely ground with a grinder (Trapp, TRF 80, Jaraguá do Sul, SC, Brazil) and mixed with soybean meal, babassu mesocarp flour, wheat bran, limestone, and mineral premix. Tifton hay was coarsely chopped to reduce the animal diet selection and feed wastage. The concentrate and Tifton hay were separately weighed using an electronic scale (Welmy, BCW 6/15/30, 1 g, Santa Bárbara d'Oeste, SP, Brazil), mixed, and offered daily. The amount of feed offered and refused was recorded daily to adjust feed offered for $100 \mathrm{~g} / \mathrm{kg}$ refusal. Both feed and orts were sampled weekly and frozen at $-18^{\circ} \mathrm{C}$ for later analysis.

To determine the average daily gain (ADG) and feed efficiency (grams of body weight gain per gram of feed), the animals were weighed every week, using an electronic scale (Welmy, W 300, $50 \mathrm{~g}$, Santa Bárbara d'Oeste, SP, Brazil).

After the feedlot period, the male goats remained in the pens for another 5 days for digestibility data collection. The leftovers were weighed at $07.30 \mathrm{~h}$ in the morning to obtain the dry matter intake (DMI) per animal and the total amount of feces generated in $24 \mathrm{~h}$. A harness equipped with a bag was used for fecal collection to prevent urine from mixing with feces. To determine the digestibility, the data of nutrient intake and leftovers were used only in these 5 days. 


\subsection{Animal Slaughter, Gastrointestinal Components, and Carcass Traits}

Before the slaughter, the male goats were kept in a solid fasting state for $16 \mathrm{~h}$ and then were weighed to determine the body weight at slaughter (BWS) on an electric scale with an accuracy of $50 \mathrm{~g}$ (Welmy, W 300, Santa Bárbara d'Oeste, SP, Brazil). The slaughter proceeded according to the guidelines recommended by the Animal Care and Use Committee of the Federal University of Maranhão (process number 23115.010734/2016-81), following the rules of the Regulation of Brazilian Industrial and Sanitary Inspection of Animal Products.

The total gastrointestinal (TGI) tract, defined by the sum of the rumen, reticulum, omasum, abomasum, and intestines weights, was removed from each carcass and immediately weighed within $60 \mathrm{~min}$ of slaughter on an electric scale with an accuracy of $2 \mathrm{~g}$ (Welmy, BCW 6/15/30, Santa Bárbara d'Oeste, SP, Brazil). These data were used to calculate the empty body weight (EBW). The components of TGI were separated and excess adipose tissue on the rumen, reticulum omasum, and abomasum was removed before weighing again, without digesta content, after being cleaned.

After the slaughter, carcasses were weighted to determine hot carcass weight on an electric scale with an accuracy of $50 \mathrm{~g}$ (Welmy, W 300, Santa Bárbara d'Oeste, SP, Brazil). After $24 \mathrm{~h}$ of cooling at $4{ }^{\circ} \mathrm{C}$, the carcasses were weighed again to obtain the cold carcass weight (CCW). Dressing percentage (DP) was calculated as follows:

$$
\mathrm{DP}=(\mathrm{HCW} / \mathrm{BWS}) \times 100
$$

where: HCW = hot carcass weight and BWS = body weight at slaughter.

The kidney fat was removed from carcass and then weighed. For the assessment of conformation, the carcasses were graded 1 (poor), 2 (fair), 3 (good), 4 (very good), or 5 (excellent) with emphasis on the following anatomical regions: hind limbs, rump, loin, shoulder, and their muscle plains.

The Longissimus lumborum (LL) muscle was transversely cut and then subcutaneous fat thickness was measured using an outside digital caliper (DIGIMESS, São Paulo, SP, Brazil). The maximum thickness of cover fat on the surface of the 13th rib, $11 \mathrm{~cm}$ from the dorso-lumbar region, was called grade ruling (GR). It was determined by the depth of the fat on the 12 th rib at $11 \mathrm{~cm}$ from the middle line loin, using the same digital caliper. The exposed side of the LL was measured using a transparent paper to draw the rib eye area (REA) [11].

The values obtained from the right and left sides of the carcass were used to calculate the arithmetic mean of the subcutaneous fat thickness and LL area per carcass. The LL was removed from the left half of the carcass of each animal and separated from the bone. It was then divided into two subsamples, which were individually vacuum-sealed, and one of them was frozen in a commercial freezer at $-18^{\circ} \mathrm{C}$ for later chemical analyses, while the samples for instrumental analyses were maintained in a refrigerator for $24 \mathrm{~h}$ to determine texture, water holding capacity, and cooking losses.

The commercial meat cuts were determined using methodologies described by [11], who cut the half carcass into the shoulder, leg, rack, and neck. The rack was divided into the rib, flank, and loin. Cut yields were estimated in relation to reconstituted cold carcass weight.

\subsection{Chemical Composition and Calculations}

After the end of the trial, samples of feed, leftovers (pooled by diet and week) and feces (100 g/kg of the total) were thawed and dried in a forced-ventilation oven $\left(55^{\circ} \mathrm{C}\right)$ for $72 \mathrm{~h}$. The samples were ground with a Wiley-type mill through a $1 \mathrm{~mm}$ screen (Marconi, Piracicaba, Brazil) for subsequent laboratory analyses according to the method of [12] for dry matter (DM; Method 930.15), ether extract (EE; Method 954.05), and nitrogen (N; Method 968.06). Crude protein (CP) was obtained by multiplying the total $\mathrm{N}$ content by 6.25. The neutral detergent fiber was assayed with a heat stable amylase according to [13].

The total carbohydrates and non-fiber carbohydrates were determined according to [14]. The total digestible nutrients (TDN) were calculated according to [15]. The metabolizable energy (ME) values for each diet were based on the assumption that $1 \mathrm{~kg}$ of TDN is equal to $4.409 \mathrm{Mcal}$ of digestible energy (DE) and $1 \mathrm{Mcal}$ of DE is equal to $0.82 \mathrm{Mcal}$ of ME [10]. 


\subsection{Physicochemical Evaluation of Meat}

The meat $\mathrm{pH}$ was measured after carcass chilling using a digital potentiometer (DIGIMED, 300M, São Paulo, Brazil) that had been calibrated with buffer solutions of $\mathrm{pH} 7.0$ and $\mathrm{pH} 4.0$. The meat color was estimated using the $\mathrm{L}^{*} \mathrm{a}{ }^{*} \mathrm{~b}$ * system using a colorimeter (Model Minolta CR-400, Minolta Co., Osaka, Japan) $24 \mathrm{~h}$ post-slaughter. Measurements were taken three times for each sample and averaged. The saturation index (Chroma) was determined using methodology by $\mathrm{a}^{*}$ and $\mathrm{b}^{*}$ data according to the formula:

$$
\text { Chroma }=\sqrt{\left(\mathrm{a}^{* 2}\right)+\left(\mathrm{b}^{* 2}\right)}
$$

The definition of Metric Hue angle $\left(\mathrm{h}^{*}\right)$ was determined using the methodology described by [16] arctangent from the ration of $b^{*}$ and $a^{*}$ data according to the formula:

$$
\mathrm{h} *=\operatorname{arctangent}(\mathrm{b} * / \mathrm{a} *)
$$

To determine the water holding capacity (WHC), the LL samples were maintained in a refrigerator for $24 \mathrm{~h}$. Meat samples weighing $500 \pm 20 \mathrm{mg}$ were placed on a filter paper between two acrylic plates, and then a $10 \mathrm{~kg}$ weight was placed on top of the plates for $5 \mathrm{~min}$. The results are expressed as percentages relative to the initial weight, as follows:

$$
\mathrm{WHC}=100-[(\mathrm{IW}-\mathrm{FW}) / \mathrm{IW} \times 100]
$$

where IW = initial weight and FW = final weight.

To measure cooking loss (CL), the samples (approximately $2.5 \mathrm{~cm}$ thick) were weighed and cooked in an industrial oven preheated to $170{ }^{\circ} \mathrm{C}$ until the internal temperature of the samples reached $71^{\circ} \mathrm{C}$, which was monitored by an internal thermocouple (iCEL TD950, Manaus, Brazil). CL was calculated as the difference between the weight of the steaks before and after oven broiling. Subsequently, these samples were then equilibrated at $4{ }^{\circ} \mathrm{C}$ overnight for instrumental texture analysis conducted according to the method of [17]. Three cores $(1.27 \mathrm{~cm}$ in diameter and $2.0 \mathrm{~cm}$ in length) were removed from each steak, parallel to the long axis of the muscle fibers using a cork borer.

The instrumental measurement of texture (kg.f) was assessed using a texture analyzer (TA-XT /Express Enhanced, Hamilton, MA, USA) equipped with a Warner-Bratzler (WB) shearing device.

\subsection{Tissue Composition}

After obtaining the tissue composition, the left legs were identified; stored in plastic bags and frozen in a freezer at $-18{ }^{\circ} \mathrm{C}$; then thawed in a refrigerator at $10^{\circ} \mathrm{C}$ for $24 \mathrm{~h}$; inside the plastic bags; then removed and weighed individually; subsequently being dissected with the help of a scalpel, to determine the composition of the tissues in fat, muscle and bone, which were individually weighed to be expressed as a percentage of the weight of the leg, as described by McCutcheon et al. [18].

\subsection{Statistical Analysis}

Data were analyzed using the MIXED procedure (SAS Inst. Inc., Cary, NC, USA) for a randomized complete design with initial weight as covariate. The homogeneity of variances was checked for each variable. The means were obtained using the LSMEANS command. When significant treatment effects were found, orthogonal polynomials for treatment were determined by linear and quadratic responses to increase the levels of BMF addition. Significance was considered at $p<0.05$.

For the subjective carcass variables (conformation and finishing), the Kruskal-Wallis' test was performed followed by Conover's procedure at $p<0.05$ significance for comparison of means. 


\section{Results}

\subsection{Growth Performance and Digestibility}

The increasing level of babassu mesocarp flour (BMF) in the diet did not change the dry matter intake (DMI) $(p=0.599)$, crude protein intake (CPI) $(p=0.126)$, and metabolizable energy intake (MEI) $(p=0.094)$ (Table 3). However, the neutral detergent fiber intake (NDFI) $(p<0.001)$ and total carbohydrates intake (TCI) $(p=0.013)$ increased linearly with BMF addition, while the ether extract intake (EEI) $(p<0.001)$ and non-fibrous carbohydrates intake (NFCI) $(p<0.001)$ decreased linearly as increasing levels of BMF were added. Because of the lack of effects on MEI (metabolizable energy intake), the final body weight $(p=0.521)$, average daily gain $(p=0.962)$, and gain:feed ratio $(p=0.529)$ also did not change with BMF addition.

Table 3. Nutrients intake, digestibility and performance of goats fed increasing levels of babassu mesocarp flour.

\begin{tabular}{|c|c|c|c|c|c|c|c|}
\hline \multirow{2}{*}{ Item } & \multicolumn{4}{|c|}{ Babassu Mesocarp Flour (g/kg DM) } & \multirow{2}{*}{ SEM $^{1}$} & \multicolumn{2}{|c|}{$p$-Value ${ }^{2}$} \\
\hline & 0 & 100 & 200 & 300 & & $\mathbf{L}$ & $\mathbf{Q}$ \\
\hline \multicolumn{8}{|c|}{ Dry matter } \\
\hline Intake (g/d) & 752.5 & 805.9 & 813.0 & 840.1 & 16.59 & 0.599 & 0.681 \\
\hline Digestibility (g/kg) & 784.6 & 798.2 & 781.3 & 764.4 & 8.62 & 0.369 & 0.422 \\
\hline \multicolumn{8}{|c|}{ Crude protein } \\
\hline Intake $(\mathrm{g} / \mathrm{d})$ & 98.1 & 107.2 & 106.2 & 107.8 & 21.43 & 0.126 & 0.356 \\
\hline Digestibility (g/kg) & 747.4 & 780.0 & 764.2 & 762.6 & 13.85 & 0.820 & 0.551 \\
\hline \multicolumn{8}{|c|}{ Neutral detergent fiber } \\
\hline Intake $(\mathrm{g} / \mathrm{d})^{3}$ & 233.9 & 288.3 & 329.8 & 398.2 & 79.23 & $<0.001$ & 0.593 \\
\hline Digestibility $(\mathrm{g} / \mathrm{kg})^{4}$ & 484.6 & 609.7 & 591.6 & 642.2 & 22.70 & 0.027 & 0.377 \\
\hline \multicolumn{8}{|c|}{ Ether extract } \\
\hline Intake $(\mathrm{g} / \mathrm{d})^{5}$ & 33.4 & 32.5 & 28.9 & 27.4 & 0.67 & $<0.001$ & 0.799 \\
\hline Digestibility $(\mathrm{g} / \mathrm{kg})^{6}$ & 872.8 & 899.6 & 893.9 & 866.3 & 6.18 & 0.654 & 0.040 \\
\hline \multicolumn{8}{|c|}{ Non-fiber carbohydrates } \\
\hline Intake $(\mathrm{g} / \mathrm{d})^{7}$ & 331.4 & 332.4 & 294.9 & 253.2 & 74.96 & $<0.001$ & 0.084 \\
\hline Digestibility (g/kg) & 957.8 & 962.9 & 983.2 & 977.9 & 5.50 & 0.170 & 0.662 \\
\hline \multicolumn{8}{|c|}{ Total carbohydrates } \\
\hline Intake $(\mathrm{g} / \mathrm{d})^{8}$ & 566.0 & 621.1 & 631.6 & 651.1 & 13.16 & 0.013 & 0.456 \\
\hline Digestibility (g/kg) & 801.9 & 816.5 & 792.5 & 777.0 & 8.65 & 0.247 & 0.416 \\
\hline \multicolumn{8}{|c|}{ Metabolizable energy } \\
\hline Intake (Mcal/d) & 2.13 & 2.37 & 2.33 & 2.37 & 0.047 & 0.094 & 0.247 \\
\hline \multicolumn{8}{|c|}{ Performance } \\
\hline Final body weight (kg) & 25.1 & 25.7 & 26.1 & 26.1 & 0.83 & 0.521 & 0.786 \\
\hline Average daily gain $(\mathrm{g} / \mathrm{d})$ & 157.4 & 163.7 & 151.2 & 160.2 & 10.13 & 0.962 & 0.943 \\
\hline Gain:feed ratio & 0.205 & 0.187 & 0.183 & 0.186 & 0.0113 & 0.529 & 0.654 \\
\hline
\end{tabular}

The babassu mesocarp flour did not change the dry matter digestibility, which averaged from 764.4 to $798.2 \mathrm{~g} / \mathrm{kg}$ (Table 3). The digestibility of crude protein $(p=0.820)$, non-fibrous carbohydrates $(p=0.170)$ and total carbohydrates $(p=0.247)$ also did not change with experimental diets, due to the similarity of the chemical composition of diets and the absence of effect on DMI. However, the neutral detergent fiber digestibility increased linearly $(p=0.027)$ and ether extract $(p=0.040)$ had a negative 
quadratic effect with BMF addition. The maximum digestibility of EE (ether extract) was $900.21 \mathrm{~g} / \mathrm{kg}$ at $147.23 \mathrm{~g} / \mathrm{kg}$ of BMF addition.

\subsection{Carcass Traits and Total Gastrintestinal Components}

The increasing levels of BMF in the diet did not change the subcutaneous fat thickness (SFT) $(p=0.257)$, body weight at slaughter (BWS) $(p=0.985)$, and consequently the hot carcass weight (HCW); $(p=0.393)$ in addition, empty body weight (EBW) $(p=0.984)$ also remained unchanged (Table 4). However, dressing percentage (DP) $(p=0.003)$ and rib eye area (REA) $(p=0.024)$ have a negative quadratic effect with maximum DP and REA, which were $499.07 \mathrm{~g} / \mathrm{kg}$ and $12.86 \mathrm{~cm}^{2}$ at $103.42 \mathrm{~g} / \mathrm{kg}$ and $120.38 \mathrm{~g} / \mathrm{kg}$ of BMF addition, respectively. While cold carcass weight (CCW) $(p=0.448)$, kidney fat $(p=0.701)$ and grade ruling (GR) $(p=0.618)$ did not change with increasing levels of BMF. The subjective evaluations, as finishing $(p=0.575)$ and conformation $(p=0.572)$, also did not change with BMF addition (Table 4).

Table 4. Carcass traits and gastrointestinal components of goats fed diets containing increasing levels of babassu mesocarp flour.

\begin{tabular}{|c|c|c|c|c|c|c|c|}
\hline \multirow{2}{*}{ Item $^{1}$} & \multicolumn{4}{|c|}{ Babassu Mesocarp Flour (g/kg DM) } & \multirow{2}{*}{ SEM $^{2}$} & \multicolumn{2}{|c|}{$p$-Value ${ }^{3}$} \\
\hline & 0 & 100 & 200 & 300 & & $\mathbf{L}$ & $\mathbf{Q}$ \\
\hline \multicolumn{8}{|c|}{ Carcass traits } \\
\hline Body weight at slaughter, kg & 24.9 & 25.9 & 25.9 & 24.8 & 0.80 & 0.985 & 0.527 \\
\hline Empty body weight, kg & 19.9 & 20.9 & 20.0 & 18.6 & 0.63 & 0.984 & 0.526 \\
\hline Hot carcass weight, $\mathrm{kg}$ & 12.1 & 12.8 & 12.8 & 11.1 & 0.38 & 0.393 & 0.150 \\
\hline Cold carcass weight, $\mathrm{kg}$ & 11.5 & 12.2 & 12.1 & 10.8 & 0.34 & 0.448 & 0.167 \\
\hline Dressing percentage, $\% 4$ & 48.8 & 49.3 & 49.4 & 44.9 & 0.51 & 0.001 & 0.003 \\
\hline SFT, $\mathrm{mm}$ & 1.01 & 1.01 & 0.93 & 0.93 & 0.312 & 0.257 & 0.994 \\
\hline Grade ruling, cm & 6.35 & 7.16 & 7.86 & 6.52 & 0.280 & 0.618 & 0.061 \\
\hline Rib eye area, $\mathrm{cm}^{2,5}$ & 11.29 & 12.29 & 11.58 & 10.50 & 0.240 & 0.122 & 0.024 \\
\hline Kidney fat, kg & 0.22 & 0.23 & 0.25 & 0.19 & 0.022 & 0.701 & 0.464 \\
\hline \multicolumn{8}{|c|}{ Subjective evaluations * } \\
\hline Conformation & $1.43 a$ & $1.57 \mathrm{a}$ & $1.67 \mathrm{a}$ & $1.43 a$ & 0.098 & \multicolumn{2}{|c|}{0.572} \\
\hline Finishing & $1.43 a$ & $1.43 a$ & $1.50 \mathrm{a}$ & $1.14 \mathrm{a}$ & 0.094 & \multicolumn{2}{|c|}{0.575} \\
\hline \multicolumn{8}{|c|}{ Gastrointestinal components } \\
\hline Total TGI, kg 6 & 3.48 & 3.52 & 3.96 & 4.61 & 0.186 & 0.001 & 0.049 \\
\hline TGI content, $\mathrm{kg}$ & 1.44 & 1.50 & 1.54 & 1.57 & 0.049 & 0.132 & 0.857 \\
\hline Rumen, $\mathrm{g} / \mathrm{kg}^{7}$ & 23.5 & 22.9 & 26.5 & 27.3 & 0.70 & 0.010 & 0.628 \\
\hline Reticulum, $\mathrm{g} / \mathrm{kg}$ & 4.50 & 4.30 & 4.50 & 4.82 & 0.012 & 0.235 & 0.212 \\
\hline Omasum, $\mathrm{g} / \mathrm{kg}^{8}$ & 3.00 & 3.82 & 3.50 & 4.82 & 0.022 & $<0.001$ & 0.062 \\
\hline Abomasum, $\mathrm{g} / \mathrm{kg}^{9}$ & 4.50 & 4.77 & 5.00 & 5.89 & 0.027 & 0.001 & 0.360 \\
\hline Large intestine, $\mathrm{g} / \mathrm{kg}$ & 14.0 & 13.3 & 14.0 & 14.9 & 0.03 & 0.218 & 0.213 \\
\hline Small intestine, $\mathrm{g} / \mathrm{kg}$ & 22.5 & 21.9 & 23.5 & 25.7 & 0.08 & 0.053 & 0.195 \\
\hline
\end{tabular}

\footnotetext{
* a,b Different lowercase letters on the same line mean different means by the Kruskal-Wallis test. ${ }^{1}$ SFT: Subcutaneous Fat Thickness; Total TGI: total gastrointestinal weight; ${ }^{2}$ Standard error of the mean; ${ }^{3}$ Effect of diet. ${ }^{4} \mathrm{y}=486.1+2.52 \mathrm{x}-0.123 \mathrm{x}^{2}, \mathrm{R}^{2}=0.9366 ;{ }^{5} \mathrm{y}=11.357+0.1252 \mathrm{x}-0.0052 \mathrm{x}^{2}, \mathrm{R}^{2}=0.9454 ;{ }^{6} \mathrm{y}=3.318+0.0038 \mathrm{x}$, $\mathrm{R}^{2}=0.8855 ;{ }^{7} \mathrm{y}=22.818+0.1493 \mathrm{x}, \mathrm{R}^{2}=0.7913 ;^{8} \mathrm{y}=3.014+0.01514 \mathrm{x}, \mathrm{R}^{2}=0.7464 ;{ }^{9} \mathrm{y}=4.380+0.0448 \mathrm{x}, \mathrm{R}^{2}=0.8892$.
}

The total TGI weight presented an increased linear effect for $(p=0.001)$. The BMF addition in the diet promoted an increased linearly effect on rumen $(p=0.010)$, omasum $(p<0.001)$, and abomasum $(p=0.001)$ (Table 4). However, it did not change $(p>0.05)$ the commercial cuts (weights and yields, Table 5). 
Table 5. Effects of increasing levels of babassu mesocarp flour in the diet of goats on weight $(\mathrm{kg})$ and yield $(\mathrm{g} / \mathrm{kg})$ of commercial cuts in relation to reconstituted half carcass.

\begin{tabular}{|c|c|c|c|c|c|c|c|}
\hline \multirow{2}{*}{ Item } & \multicolumn{4}{|c|}{ Babassu Mesocarp Flour (g/kg DM) } & \multirow{2}{*}{ SEM $^{1}$} & \multicolumn{2}{|c|}{$p$-Value ${ }^{2}$} \\
\hline & 0 & 100 & 200 & 300 & & L & $Q$ \\
\hline \multicolumn{8}{|c|}{ Shoulder } \\
\hline $\mathrm{kg}$ & 1.21 & 1.26 & 1.26 & 1.13 & 0.034 & 0.420 & 0.215 \\
\hline $\mathrm{g} / \mathrm{kg}$ & 212.7 & 210.6 & 210.9 & 212.7 & 2.18 & 0.949 & 0.383 \\
\hline \multicolumn{8}{|c|}{ Leg } \\
\hline $\mathrm{kg}$ & 1.72 & 1.86 & 1.83 & 1.65 & 0.041 & 0.503 & 0.057 \\
\hline $\mathrm{g} / \mathrm{kg}$ & 303.3 & 310.5 & 310.8 & 311.1 & 2.69 & 0.507 & 0.939 \\
\hline \multicolumn{8}{|c|}{ Rib } \\
\hline $\mathrm{kg}$ & 1.61 & 1.69 & 1.65 & 1.45 & 0.057 & 0.283 & 0.227 \\
\hline $\mathrm{g} / \mathrm{kg}$ & 279.3 & 283.3 & 275.7 & 270.0 & 3.65 & 0.307 & 0.789 \\
\hline \multicolumn{8}{|c|}{ Flank } \\
\hline $\mathrm{kg}$ & 0.23 & 0.24 & 0.26 & 0.24 & 0.010 & 0.651 & 0.583 \\
\hline $\mathrm{g} / \mathrm{kg}$ & 41.00 & 40.5 & 43.2 & 46.2 & 0.11 & 0.091 & 0.374 \\
\hline \multicolumn{8}{|c|}{ Loin } \\
\hline $\mathrm{kg}$ & 0.49 & 0.46 & 0.48 & 0.40 & 0.020 & 0.171 & 0.621 \\
\hline $\mathrm{g} / \mathrm{kg}$ & 85.4 & 77.5 & 79.8 & 76.3 & 0.16 & 0.810 & 0.368 \\
\hline \multicolumn{8}{|c|}{ Neck } \\
\hline $\mathrm{kg}$ & 0.45 & 0.46 & 0.48 & 0.44 & 0.019 & 0.920 & 0.564 \\
\hline $\mathrm{g} / \mathrm{kg}$ & 78.1 & 77.4 & 80.3 & 83.4 & 2.28 & 0.348 & 0.581 \\
\hline
\end{tabular}

\subsection{Instrumental Evaluation of Meat and Tissue Composition}

The increasing levels of BMF did not change the contents of moisture $(p=0.262)$, protein $(p=0.525)$, ash $(p=0.769)$, and fat $(p=0.584)$ (Table 6$)$. The $\mathrm{pH}(p=0.266)$, water holding capacity (WHC) $(p=0.071)$, cooking loss (CL) $(p=0.640)$, and shear force (SF) $(p=0.267)$ also did not change. The $\mathrm{L}^{*}(p=0.061)$, $\mathrm{a}^{*}(p=0.315), \mathrm{b} *(p=0.279)$, chroma index (indicating the color saturation) $(p=0.872)$, and $\mathrm{h}^{*}(p=0.057)$ also did not change with experimental diets (Table 6).

There was a quadratic effect for leg weight $(p=0.045)$ and muscle weight $(p=0.049)$ (Table 7). The BMF addition did not change the weight and yields of bone $(p=0.184 ; p=0.726)$ and fat $(p=0.408 ; p=0.653)$, and the tissue proportions as the muscle:bone $(p=0.583)$ ratio and the muscle:fat ratio $(p=0.436)$. 
Table 6. Physicochemical composition and color parameters (Lightness L *; redness a *; yellowness b *; Color saturation index Chroma; Hue angle $\mathrm{h} *$ ) of the meat from goats fed with levels of babassu mesocarp flour diets.

\begin{tabular}{|c|c|c|c|c|c|c|c|}
\hline \multirow{2}{*}{ Item $^{1}$} & \multicolumn{4}{|c|}{ Babassu Mesocarp Flour (g/kg DM) } & \multirow{2}{*}{ SEM $^{2}$} & \multicolumn{2}{|c|}{$p$-Value ${ }^{3}$} \\
\hline & 0 & 100 & 200 & 300 & & $\mathbf{L}$ & $\mathbf{Q}$ \\
\hline \multicolumn{8}{|c|}{ Proximate chemical composition $(\mathrm{g} / \mathrm{kg})$} \\
\hline Moisture & 755.2 & 754.4 & 762.2 & 762.9 & 2.83 & 0.262 & 0.946 \\
\hline Protein & 218.4 & 215.7 & 223.2 & 221.9 & 3.01 & 0.525 & 0.932 \\
\hline Ash & 11.7 & 10.5 & 11.5 & 11.0 & 0.28 & 0.769 & 0.494 \\
\hline Fat & 48.2 & 55.1 & 42.0 & 48.0 & 0.26 & 0.584 & 0.795 \\
\hline \multicolumn{8}{|c|}{ Physical characteristics } \\
\hline $\mathrm{pH}$ & 5.79 & 5.74 & 5.67 & 5.71 & 0.027 & 0.266 & 0.443 \\
\hline WHC, \% & 67.98 & 64.50 & 62.62 & 64.18 & 0.792 & 0.071 & 0.126 \\
\hline Cooking loss, $\%$ & 41.54 & 43.24 & 43.32 & 42.00 & 0.626 & 0.640 & 0.341 \\
\hline Shear force, kg.f & 4.84 & 5.66 & 5.60 & 6.01 & 0.355 & 0.267 & 0.842 \\
\hline \multicolumn{8}{|c|}{ Meat color } \\
\hline $\mathrm{L}^{*}$ & 39.1 & 39.0 & 41.6 & 43.6 & 0.53 & 0.061 & 0.230 \\
\hline$a^{*}$ & 17.7 & 16.6 & 18.4 & 16.7 & 0.36 & 0.315 & 0.877 \\
\hline$b^{*}$ & 3.90 & 3.39 & 4.45 & 4.07 & 0.169 & 0.279 & 0.812 \\
\hline Chroma & 18.1 & 16.9 & 18.9 & 17.2 & 0.38 & 0.872 & 0.756 \\
\hline $\mathrm{h} *, 4$ & 12.4 & 11.5 & 13.6 & 13.7 & 0.59 & 0.057 & 0.355 \\
\hline
\end{tabular}

${ }^{1}$ WHC: water holding capacity; ${ }^{2}$ Standard error of the mean; ${ }^{3}$ Effect of diet; ${ }^{4}$ Hue angle.

Table 7. Mean tissue composition of leg from goats fed diets containing increasing levels of babassu mesocarp flour.

\begin{tabular}{|c|c|c|c|c|c|c|c|}
\hline \multirow{2}{*}{ Item. } & \multicolumn{4}{|c|}{ Babassu Mesocarp Flour (g/kg DM) } & \multirow{2}{*}{ SEM $^{1}$} & \multicolumn{2}{|c|}{$p$-Value ${ }^{2}$} \\
\hline & $\mathbf{0}$ & 100 & 200 & 300 & & $\mathbf{L}$ & $\mathbf{Q}$ \\
\hline \multicolumn{8}{|c|}{ Leg weight } \\
\hline$(\mathrm{kg})^{3}$ & 1.60 & 1.74 & 1.64 & 1.50 & 0.041 & 0.271 & 0.045 \\
\hline \multicolumn{8}{|c|}{ Bone } \\
\hline $\mathrm{kg}$ & 0.37 & 0.41 & 0.35 & 0.35 & 0.010 & 0.184 & 0.570 \\
\hline $\mathrm{g} / \mathrm{kg}$ & 231.3 & 235.6 & 213.4 & 233.3 & 3.23 & 0.726 & 0.087 \\
\hline \multicolumn{8}{|c|}{ Muscle } \\
\hline $\mathrm{kg}^{4}$ & 0.82 & 0.87 & 0.87 & 0.78 & 0.018 & 0.539 & 0.049 \\
\hline $\mathrm{g} / \mathrm{kg}$ & 512.5 & 500.0 & 530.5 & 520.0 & 5.69 & 0.340 & 0.583 \\
\hline \multicolumn{8}{|c|}{ Fat } \\
\hline $\mathrm{kg}$ & 0.13 & 0.14 & 0.15 & 0.10 & 0.009 & 0.408 & 0.065 \\
\hline $\mathrm{g} / \mathrm{kg}$ & 81.2 & 80.4 & 91.4 & 66.6 & 4.78 & 0.653 & 0.075 \\
\hline \multicolumn{8}{|c|}{ Tissue } \\
\hline $\mathrm{kg}$ & 0.16 & 0.17 & 0.16 & 0.14 & 0.007 & 0.366 & 0.261 \\
\hline $\mathrm{g} / \mathrm{kg}$ & 100.0 & 97.7 & 97.6 & 93.3 & 3.74 & 0.611 & 0.665 \\
\hline \multicolumn{8}{|c|}{ Proportions } \\
\hline Muscle:Bone & 2.23 & 2.13 & 2.50 & 2.20 & 0.051 & 0.583 & 0.277 \\
\hline Muscle:Fat & 7.27 & 6.48 & 5.93 & 6.90 & 0.581 & 0.436 & 0.173 \\
\hline
\end{tabular}




\section{Discussion}

Growth performance was not affected by increasing levels of BMF, as evidenced by the lack of effect on DMI and MEI. The decrease of NFCI as BMF was added in the diets, is due to this co-product having lower NFC than ground corn.

The linear increase of NDFI is a consequence of higher neutral detergent fiber (NDF) levels in diets with BMF. Despite the BMF having a significant starch content [19], after mesocarp extraction, the flour may contain small amounts of epicarp and endocarp, resulting in a BMF with a greater fiber content and low starch content $[7,20]$, which is likely for the BMF used in this study.

A study with cattle [21] also reported an increase of NDFI when $600 \mathrm{~g} / \mathrm{kg}$ BMF was added to the concentrate. In all treatments evaluated, except for the control diet, male goats had NDFI greater than the limit $(12.0 \mathrm{~g} / \mathrm{kg}$ of BW) for ruminant species, which could reduce the DMI because of the effect of the rumen filling [22]. However, because of the fine particle of BMF, this filling effect was not observed, and the DMI was regulated by factors related to the energy demands of animals [22,23] and, despite the higher NDF contents in diets with increasing concentrations of BMF, the energy contents among diets and MEI were similar, resulting in these findings.

Although changes in kinetics of fermentation have been reported to result in a decrease of ruminal fermentation [4,24] and NDF digestibility [3] with BMF addition, because of the higher acid detergent fiber (ADF) content [25] in BMF, in this study, the NDF digestibility increased linearly.

It has been suggested that goats have a higher number of cellulolytic bacteria [8] and microbial protein production [26]. These factors could contribute to the results that differed from results reported with lambs [3]. However, the rate of digestion was related more to the diet than to the animal species consuming the diet [27]. Thus, changes in chemical, physical and nutritional values of agricultural co-products depend on the variety of products used, methods of processing and storage, among many factors [28].

It is likely that this fact contributed to increased linear effect on total TGI weight and proportions of rumen, omasum, abomasum, and small intestine, because of the little distension effect, as the inclusion of BMF did not change BWS, HCW and CCW (cold carcass weight). These increased linear effects on total TGI weight have promoted the quadratic effect on dressing percentage. In Northeast of Brazil, the components of non-carcass characteristics, such as TGI components, are very important for typical food, such as "buchada caprina", and these parts increase the value added to the carcass [29], even with lower dressing percentages.

The rib eye area corresponded to the muscle deposition in the carcass, an important parameter because the meat is the tissue with higher commercial value. Among the commercial cuts of the carcass, the leg is the most important [30]. The lack of BMF effect on the muscle proportion of legs confirmed the potential of using this co-product. However, a negative quadratic effect on fat proportion was observed, which is an important component that protects the muscle during cooling against dryness, and because of this, a quadratic effect on leg weights after they thawed in a refrigerator was observed.

The absence effects of BMF addition on physical and chemical characteristics of meat is a consequence of minor effects of BMF on nutritional parameters. The meat $\mathrm{pH}$ values were within the range considered essential for the proper establishment of rigor mortis and are close to those reported by other studies for goat species [31,32]. The $\mathrm{pH}$ means were a little higher than the isoelectric point of myofibrillar proteins (5.2-5.3), which is a favorable result, because it is above the neutral charge and has an excessive negative charge that provides filament repulsion. This makes room for water molecules to bind, thus increasing moisture in the flesh, which can contribute to greater juiciness, lower mechanical force when cutting and lower proportional losses of water during cooking [33].

The increasing levels of BMF also did not change the physical traits of meat, such as WHC, and consequently cooking loss and shear force. The WHC represents the meat capacity to retain water during the application of external forces, and may be determined by several factors, including post-mortem glycolysis, $\mathrm{pH}$, and cooling of the carcass [34]. Although the shear force did not change with BMF addition, the values found were slightly higher than other studies with goats $[30,32,34]$. 
The lack of subcutaneous fat thickness increases the probability of cold shortening during rapid chilling of carcasses, resulting in less tender meat [35]. Moreover, the slight increase in shear force values can be associate of meat from older goats, as used in this study, because of the preference of local consumers.

Adipose depots develop in a preferential order; visceral fat (omental, mesenteric, kidney and pericardial) is the earliest developing depot followed by intermuscular, subcutaneous, and intramuscular fat [36]. In this study, the diet effect on fat deposition was not observed on subcutaneous fat thickness, or intramuscular fat, or kidney fat. The comparatively poor fat covering of goat carcasses means that the criterion of subcutaneous fatness, which is a reliable predictor of yield in lamb carcass, is not suitable for classifying and grading goat carcasses and contributed to the downgrading of goat carcasses in several commercial enterprises [37].

Thus, our hypothesis that BMF should not impact the carcass characteristics of male goats is not supported by our data. Nevertheless, growth performance and meat quality did not change with BMF addition.

\section{Conclusions}

The addition of BMF up to $200 \mathrm{~g} / \mathrm{kg}$ in the diet of male goat can improve the dressing percentage without major changes in physical and chemical traits, representing an attractive product for consumers because of the good values for luminosity.

Author Contributions: Conceptualization, A.R.D.S., J.N.C.S., H.N.P., G.S.O., A.M.Z., D.J.F., J.S.A., A.A.A. and M.O.M.P.; Data curation, A.R.D.S., J.N.C.S., H.N.P., G.S.O. and M.O.M.P.; Formal analysis, A.R.D.S., J.N.C.S., H.N.P., A.M.Z., D.J.F., A.G.V.O.L., J.S.A., A.A.A. and M.O.M.P.; Funding acquisition, H.N.P. and M.O.M.P.; Investigation, A.R.D.S., J.N.C.S., H.N.P., G.S.O. and M.O.M.P.; Methodology, A.R.D.S., J.N.C.S., H.N.P., G.S.O., K.S.R. and M.O.M.P.; Project administration, H.N.P., A.M.Z., D.J.F. and M.O.M.P.; Resources, A.R.D.S., J.N.C.S., H.N.P., G.S.O. and M.O.M.P.; Software, A.R.D.S., J.N.C.S., G.S.O., K.S.R., A.G.V.O.L. and M.O.M.P.; Supervision, H.N.P., A.M.Z. and M.O.M.P.; Validation, H.N.P., A.M.Z., D.J.F. and M.O.M.P.; Visualization, A.R.D.S., H.N.P., A.M.Z. and M.O.M.P.; Writing-original draft, A.R.D.S., J.N.C.S. and M.O.M.P.; Writing-review \& editing, A.R.D.S., H.N.P., A.M.Z. and M.O.M.P. All authors have read and agreed to the published version of the manuscript.

Funding: This research was funded by Foundation for Research Support of the State of Maranhão (FAPEMA), number 00752/16.

Acknowledgments: We are grateful to Coordination for the Improvement of Higher Education Personnel (CAPES) for the scholarship of the first two authors.

Conflicts of Interest: The authors declare no conflict of interest.

\section{References}

1. States United Department of Agriculture, Foreign Agriculture Service: World Market and Trade. USA: USDA/FAS. Available online: https://apps.fas.usda.gov/psdonline/circulars/grain.pdf (accessed on 28 March 2020).

2. Zanine, A.M.; Fonseca, A.A.; Ribeiro, M.D.; Leonel, F.P.; Ferreira, D.J.; Souza, A.L.; Silva, F.G.; Correa, R.A.; Negrão, F.M.; Pinho, R.M.A. Intake, digestibility and feeding behaviour of grazing dairy cows supplemented with common bean (Phaseolus vulgaris L.) residue. Anim. Prod. Sci. 2020, 1, 1-7. [CrossRef]

3. Gerude Neto, O.J.A.; Parente, H.N.; Parente, M.O.M.; Alves, A.A.; Santos, P.A.C.; Moreira Filho, M.A.; Zanine, A.M.; Ferreira, D.J.; Bezerra, L.R.; Gomes, R.M.S. Intake, nutrient apparent digestibility, and ruminal constituents of crossbred Dorper $\times$ Santa Inês sheep fed diets with babassu mesocarp flour. Sci. World J. 2016, 10, 1-8. [CrossRef] [PubMed]

4. Santos, P.A.C.; Parente, M.O.M.; Parente, H.N.; Zanine, A.M.; Moreira Filho, M.A.; Alves, A.A.; Ferreira, D.J.; Gomes, R.M.S.; Fernandes, V.L. Babassu mesocarp flour in diet of finishing lambs. Ital. J. Anim. Sci. 2018, 49, 1-10. [CrossRef]

5. Albiero, D.; Maciel, A.J.S.; Gamero, C.A. Development and design of a harvester babassu (Orbignya phalerata Mart.) for family farmers in the transitional forest regions for the Amazon. Acta Amaz. 2011, 41, 57-68. [CrossRef]

6. Soler, M.P.; Vitali, A.A.; Muto, E.F. Technology of breaking the babassu coconut (Orbignya speciosa). Food Technol. Sci. 2007, 27, 717-722. [CrossRef] 
7. Cinelli, B.A.; Lopez, J.A.; Castilho, L.R.; Freire, D.M.; Castro, A.M. Granular starch hydrolysis of babassu agroindustrial residue: A bioprocess within the context of biorefinery. Fuel 2014, 124, 41-48. [CrossRef]

8. Gihad, E.A.; El Bedawy, T.M.; Mehrez, A.Z. Fiber digestibility by goats and sheep. J. Dairy Sci. 1980, 63, 1701-1706. [CrossRef]

9. Santos, A.R.D.; Parente, H.N.; Machado, N.A.F.; Araújo, J.S.; Ferreira, D.J.; Rocha, K.S.; Anjos, L.F.; Portela, Y.N.; Sousa, M.N.; Zanine, A.M.; et al. The physiological response, feeding behaviour and water intake of goat kids fed diets with increasing levels of babassu mesocarp flour. Biol. Rhythm Res. 2019, 50, 1-14. [CrossRef]

10. National Research Council. Nutrient Requirements of Small Ruminants: Sheep, Goats, Cervids, and New World Camelids; National Academy Press: Washington, DC, USA, 2007.

11. Santos, F.M.; Araújo, G.G.L.; Souza, L.L.; Yamamoto, S.M.; Queiroz, M.A.A.; Lanna, D.P.D.; Moraes, S.A. Impact of water restriction periods on carcass traits and meat quality of feedlot lambs in the Brazilian semi-arid region. Meat Sci. 2019, 156, 196-204. [CrossRef]

12. Association of Official Analytical Chemists. Official Methods of Analysis, 19th ed.; AOAC: Gaithersburg, MD, USA, 2012.

13. Mertens, D.R. Gravimetric determination of amylase-treated neutral detergent fibre in feeds with refluxing in beakers or crucibles: Collaborative study. J. AOAC Int. 2012, 85, 1217-1240. [CrossRef]

14. Sniffen, C.J.; O'Connor, J.D.; Van Soest, P.J.; Fox, D.G.; Russell, J.B. A net carbohydrate and protein system for evaluating cattle diets: II Carbohydrate and protein. J. Anim. Sci. 1992, 70, 3562-3577. [CrossRef] [PubMed]

15. Weiss, W.P.; Conrad, H.R.; Pierre, N.R.S. A theoretically-based model for predicting total digestible nutrient values of forages and concentrates. J. Anim. Sci. Technol. 1992, 39, 95-110. [CrossRef]

16. Hunt, M.C.; King, A. Meat Color Measurement Guidelines; American Meat Science Association: Champaign, IL, USA, 2012; pp. 15-17.

17. American Meat Science Association. Research Guidelines for Cookery, Sensory Evaluation and Tenderness Measurements of Fresh Meat; AMSA: Champaign, IL, USA, 2015.

18. McCutcheon, S.N.; Blair, H.T.; Purchas, R.W. Body composition and organ weights in fleece weight-selected and control Romney rams. Int. J. Agric. Res. 1993, 36, 445-449. [CrossRef]

19. Sá, H.C.M.; Borges, I.; Macedo Junior, G.L.; Neiva, J.N.M.; Sousa, L.F. Babassu cored flour in diets formulation for sheep. Caatinga Res. 2015, 28, 207-216.

20. Carneiro, M.I.F.; Sakomura, N.K.; Kawauchi, I.M.; Silva, E.P.; Araújo, J.A.; Fernandes, J.B.K.; Gomes Filho, J.S. Evaluation of babassu mesocarp meal in feed for broiler chickens. Ars. Vet. 2013, 29, 175-182. [CrossRef]

21. Silva, N.R.; Ferreira, A.C.H.; Faturi, C.; Silva, G.F.; Missio, R.L.; Neiva, J.N.M.; Araújo, V.L.; Alexandrino, E. Performance in feedlot beef cattle, bulls or not, fed with increasing levels of babassu mesocarp meal. Rural Sci. 2012, 42, 1882-1887. [CrossRef]

22. Mertens, D.R. Regulation of forage intake. In Forage Quality, Evaluation and Utilization; Fahey Junior, G.C., Ed.; American Society of Agronomy: Madison, WI, USA, 1994; pp. 450-493.

23. Forbes, J.M. Voluntary feed intake. In Quantitative Aspects of Ruminant Digestion and Metabolism; Forbes, J.M., France, J., Eds.; CAB International: Wallingford, UK, 1993; pp. 479-494.

24. Sousa, L.F.; Macedo Júnior, G.D.L.; Santos, R.P.; Silva, A.G.M.; Borges, I. Bromatological composition and kinetics of rumen fermentation for feeds containing babassu residue. Res. Sci. Agric. 2014, 45, 177-185. [CrossRef]

25. Van Soest, P.J. Nutritional Ecology of the Ruminant, 2nd ed.; Cornell University: Ithaca, NY, USA, 1994.

26. Hadjipanayiotou, M.; Antoniou, T.A. Comparison of rumen fermentation patterns in sheep and goats given a variety of diets. J. Sci. Food Agric. 1983, 341, 319-1322. [CrossRef]

27. Huston, J.E.; Rector, B.S.; Ellis, W.C.; Allen, M.L. Dynamics of Digestion in Cattle, Sheep, Goats and Deer. J. Anim. Sci. 1986, 62, 208-215. [CrossRef]

28. Lousada Júnior, J.E.; Costa, J.M.C.; Neiva, J.N.M.; Rodriguez, N.M. Physical characterization of by-products obtained from fruit processing that can be used in animal feed. Agron. Sci. J. 2006, 27, 70-76.

29. Santos, N.M.; Costa, R.G.; Madruga, M.S.; Medeiros, A.N.; Albuquerque, C.L.C.; Queiroga, R.C.R.E. Constitution and composition chemistry of the precooked goat like Buchada produced in the state of Paraiba. Braz. Braz. Arch. Biol. 2008, 51, 793-798. [CrossRef] 
30. Silva, T.M.; Medeiros, N.A.; Oliveira, R.L.; Gonzaga Neto, S.; Queiroga, R.C.R.; Ribeiro, R.D.X.; Leão, A.G.; Bezerra, L.R. Carcass traits and meat quality of crossbred Boer goats fed peanut cake as a substitute for soybean meal. J. Anim. Sci. 2016, 94, 2992-3002. [CrossRef] [PubMed]

31. Sañudo, C.; Campo, M.M.; Muela, E.; Olleta, J.L.; Delfa, R.; Jiménez-Badillo, R.; Alcalde, M.J.; Horcada, A.; Oliveira, I.; Cilla, I. Carcass characteristics and instrumental meat quality of suckling kids and lambs. Span. J. Agric. Res. 2012, 10, 690-700. [CrossRef]

32. Yalcintan, H.; Akin, P.D.; Ozturk, N.; Ekiz, B.; Kocak, O.; Yilmaz, A. Carcass and meat quality traits of Saanen goat kids reared under natural and artificial systems and slaughtered at different ages. Acta Vet. Brno 2018, 87, 293-300. [CrossRef]

33. Lawrie, R.A. The Science Meat, 6th ed.; Artmed: Porto Alegre, Brazil, 2005.

34. Lopes, L.S.; Martins, S.R.; Chizzotti, M.L.; Busato, K.C.; Oliveira, I.M.; Machado Neto, O.R.; Paulino, P.V.R.; Lanna, D.P.D.; Ladeira, M.M. Meat quality and fatty acid profile of Brazilian goats subjected to different nutritional treatments. Meat Sci. 2014, 97, 601-608. [CrossRef] [PubMed]

35. Kannan, G.; Lee, J.H.; Kouakou, B. Chevon quality enhancement: Trends in pre- and post-slaughter techniques. Small Rumin. Res. 2014, 121, 80-88. [CrossRef]

36. Casey, N.H.; Van Niekerk, W.A.; Webb, E.C. Goat meat. In Encyclopaedia of Food Sciences and Nutrition; Caballero, B., Trugo, L., Finglass, P., Eds.; Academic Press: London, UK, 2003; pp. 2937-2944.

37. Simela, L.; Ndlovu, L.R.; Sibanda, L.M. Carcass characteristics of marketed Matebele goats from south-western Zimbabwe. Small Rumin. Res. 1999, 32, 173-179. [CrossRef]

(C) 2020 by the authors. Licensee MDPI, Basel, Switzerland. This article is an open access article distributed under the terms and conditions of the Creative Commons Attribution (CC BY) license (http://creativecommons.org/licenses/by/4.0/). 